\title{
A study of white mica microstructure and microchemistry in a low grade mylonite
}

\author{
J. H. BehrmanN* \\ Department of Geology and Mineralogy, University of Oxford, Parks Road, Oxford OX1 3PR. U.K.
}

(Received 11 March 1983; accepted in revised form 12 September 1983)

\begin{abstract}
A suite of mylonites rich in white mica, taken from the Betic Movement Zone (Sierra Alhamilla Spain) shows progressive grain refinement involving a two-stage recrystallization history. Stage one is isochemical and possibly works by nucleation and growth of new crystals at sites of fracture and dilatancy. Stage two is nonisochemical and may be driven by differences in strain energy and chemical free energy between the two phases. Deformation is probably governed by brittle fracture and diffusional mass transfer along grain boundaries and cracks. The two stages of recrystallization are thought to represent a single progressive episode of deformation under changing metamorphic conditions.
\end{abstract}

\section{INTRODUCTION}

WHITE mica is one of the major constituents of low grade metamorphic rocks. Its deformational behaviour has become increasingly well understood in slates (e.g. Plessmann 1964, Knipe 1981, Weber 1981). Apart from a study of the microstructure of a sheared pegmatite (Wilson 1980), phyllosilicate rich low-grade mylonites have received little or no attention. Bell \& Etheridge (1973) noted that mylonite formation may imply an interplay of ductile and brittle deformation on a grain scale, generally producing fine grained mineral aggregates. Common mesoscopic features are a strong, platy foliation and a lineation due to elongated grains or grain aggregates.

Previous examination of deformed muscovite on a grain scale (Bell \& Wilson 1981) shows.little change of microstructural characteristics in the transmission electron microscope (TEM) with variation of strain. An intracrystalline grain size reduction process by subgrain formation and rotation ( $\mathrm{Li} \mathrm{1962,} \mathrm{Poirier} \mathrm{\&} \mathrm{Guillopé}$ 1979) seems to be difficult to achieve in phyllosilicates because of the abundance of partial dislocations and the lack of unit dislocations. This makes climb processes difficult to activate. Deformation induced recrystallization should therefore either involve bulge nucleation (Bailey \& Hirsch 1962) or nucleation and growth of entirely new crystals.

This study will attempt to:

(1) elucidate the nature of the recrystallization process responsible for grain size reduction in white mica;

(2) understand the deformation mechanisms of polycrystalline white mica in low grade mylonite and

(3) investigate deformation induced variations in microchemistry and composition-volume relationships.

* Present address: BP Minerals International Ltd., Old Edinburgh Airport, Turnhouse Road. Edinburgh EH12 OAL. U.K..

\section{STRUCTURAL SETTING}

Naturally deformed samples have been collected from two mylonite belts in the central Sierra Alhamilla, southern Spain (Fig. 1). These mylonites form part of the Betic Movement Zone (Platt \& Vissers 1980) which marks the contact between the two major tectonic complexes in the internal, metamorphic segment of the Betic orogen (Betic Zone). The Nevado-Filabride complex and the overlying Higher Betic nappes (Fig. 1) can be distinguished on the basis of their different Alpine metamorphic evolutions (Torres-Roldán 1979), and different litho-stratigraphic sequences (Egeler \& Simon 1969).

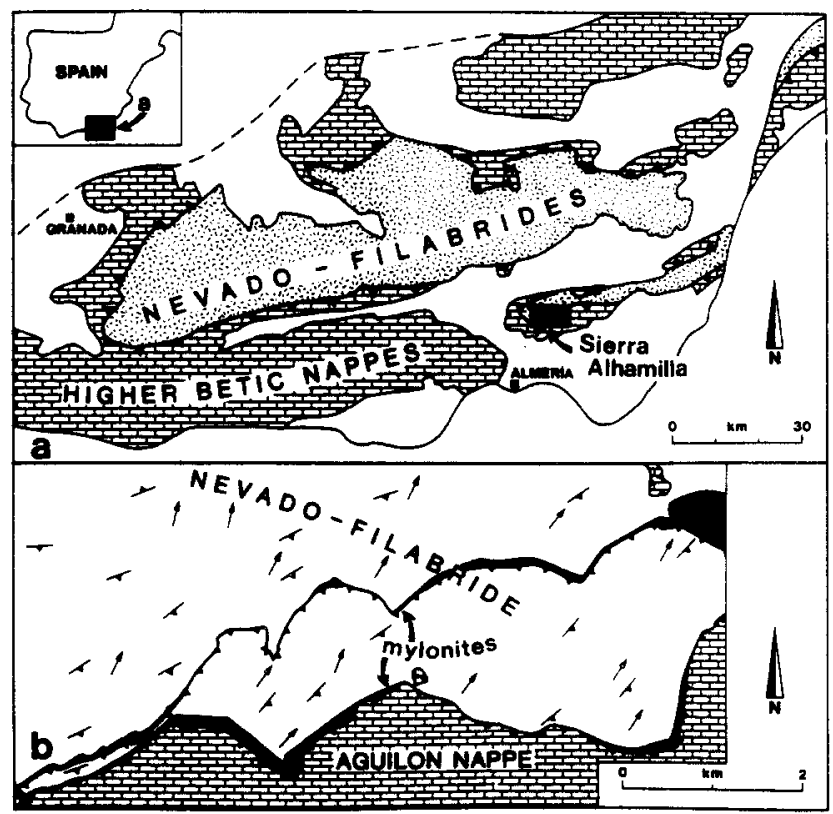

Fig. 1. (a) Tectonic sketch of the eastern Betic Zone. (b) Tectonic sketch of the central Sierra Alhamilla. One of the two mylonite belts separates two structural units within the Nevado-Filabride complex. The penetrative schistosity related to nappe emplacement and the tectonic contacts dip S-SE at moderate angles. The trend of associated stretching lineations is marked by arrows. (After Behrmann \& Platt 1982.) 
In the Sierra Alhamilla, upper greenschist to amphibolite facies rocks of the Nevado-Filabride complex have undergone large strain contact deformation and retrograde metamorphism in a zone several hundred metres thick concurrent with the emplacement of the overlying Higher Betic nappes (Behrmann \& Platt 1982, Platt 1982). The protoliths of the micaceous mylonites were light green to dark, coarse grained schists of variable composition, consisting mainly of quartz and white mica. Numerous porphyroclasts of garnet, plagioclase, staurolite, kyanite, or andalusite suggest an initial grain size of up to $1 \mathrm{~cm}$. A strong foliation is defined by compositional variations on a millimetre scale, shape preferred orientation of white mica, and elongate grain aggregates of quartz. The quartz shows almost complete dynamic recrystallization to $7-10 \mu \mathrm{m}$ subequant grains. Sets of extensional crenulation cleavage are common (Platt \& Vissers 1980).

\section{PREPARATION PROCEDURE}

Two sets of petrographic thin sections were cut at right angles to the foliation, parallel and perpendicular to the lineation, respectively. From these, thin foils from selected specimen areas were prepared for electron microscopy by ion bombardment (Barber 1970) and examined in a JEM $100 \mathrm{C}$ transmission electron microscope with contrast enhancing equipment at $100 \mathrm{kV}$. The polished thin section used for scanning electron microscopy was etched by immersing it in $10 \%$ hydrofluoric acid for five seconds.

Microprobe analyses were performed on polished thin sections in a Cambridge Microscan 9 electron microprobe fitted with a wavelength dispersive analyzer, operating at $20 \mathrm{kV}$ and $35 \mathrm{nA}$. The spot size was chosen to be $3 \times 3 \mu \mathrm{m}$, to approximate analysis of single mica grains. An automatic Seiffert-Scintag texture goniometer operating in combined reflection and transmission modes (Siddans 1976) was used to measure the X-ray pole figures. Azimuth and tilt step sizes were $5^{\circ}$, counting time was $40 \mathrm{~s}$ for background measurements, and $10 \mathrm{~s}$ for every position on the tilt small circles.

\section{OPTICAL MICROSTRUCTURE}

Three different types of white mica grains can be distinguished on the scale of the optical microscope: $(A)$ large $(>1 \mathrm{~mm})$ porphyroclasts of muscovite, having 'fish' shapes elongate in the foliation and showing slight bending or microfolding (Fig. 2a) of (001). Grain boundaries in microfold hinges are serrated. The microfold axes are sub-parallel to the stretching lineation defined by the elongate aggregates of quartz in the specimens. $(B)$ Muscovite aggregates of up to $200 \mu \mathrm{m}$ grain size. Twenty or so of these grains sometimes form outlines of the large type- $A$ porphyroclasts (Fig. 2b). Grain shapes are equant or elongate in (001), the elongate grains usually having a small to moderate (up to $30^{\circ}$ ) crystallog- raphic mismatch with each other. Grain boundaries are sometimes stepped, or serrated. Type- $A$ and $-B$ white mica are colourless and without pleochroism in plane polarized light. $(C)$ Frequently, type- $A$ and $-B$ grain assemblages are cut by extensional crenulation cleavages (Figs. $2 \mathrm{c} \& \mathrm{~d}$ ). The cleavage zones are usually $10-30 \mu \mathrm{m}$ wide, and consist of a very fine grained $(<5 \mu \mathrm{m})$ mica with a light brownish-green colour and a marked pleochroism. In the most deformed specimens the bulk of the rock is made up of this variety. The grains have a shape and crystallographic preferred orientation, with (001) parallel to the extensional crenulation cleavage or the main foliation, respectively.

\section{EM MICROSTRUCTURE}

Observation of microstructures in TEM is mostly restricted to a single grain scale, or to grain boundaries, because of the lack of sufficiently large areas of thin foil. Therefore, a large type- $A$ porphyroclast was examined in scanning electron microscope (SEM) (Fig. 3a). The crystal contains large dilation cracks parallel to (001). The picture suggests that they may have been produced by shear and intracrystalline glide inhibition along $(001)$. In many cases these dilation cracks are filled with either type- $C$ white mica, fine grained chlorite, or quartz. Preferential etching of chlorite has resulted in the void observed in Fig. 3(a). The areas of preferential etching are interpreted to reflect different densities of stacking faults or dislocations within the large crystal of white mica.

TEM observations on type- $B$ muscovite reveal lattice bending around axes lying within the basal plane, accompanied by formation of (001) cleavage and opening of dilation cracks (Fig. 3b). The curvature of (001) can be accommodated by arrays of either unit or partial dislocations producing images very similar to those documented by Bell \& Wilson (1981). Steps and offsets of grain boundaries at low angles to the basal planes of the neighbouring crystals are fairly common. This could be what is referred to as 'serrate' in the optical microstructure description.

Type- $C$ grains show far less lattice bending than type$A$ and - $B$ grains (Fig. $3 c$ ), and the dislocation substructure observed is restricted to partials terminating stacking faults. Stacking disorder arises from growth interlayering of $14 \AA$ chlorite in $10 \AA$ white mica domains (Fig. 3d). A second type of stacking disorder results in regions of $20 \AA$ superlattices. Cleavage formation parallel to (001) is common, but no significant dilation along them is observed. Grain boundaries with tilt mismatches as low as $3^{\circ}$ are sharply defined, decorated with smoothedged voids $(0.1 \mu \mathrm{m}$ long), and show the occasional offset.

\section{CRYSTALLOGRAPHIC PREFERRED ORIENTATION}

The spatial intensities of white mica (110) and (114) 


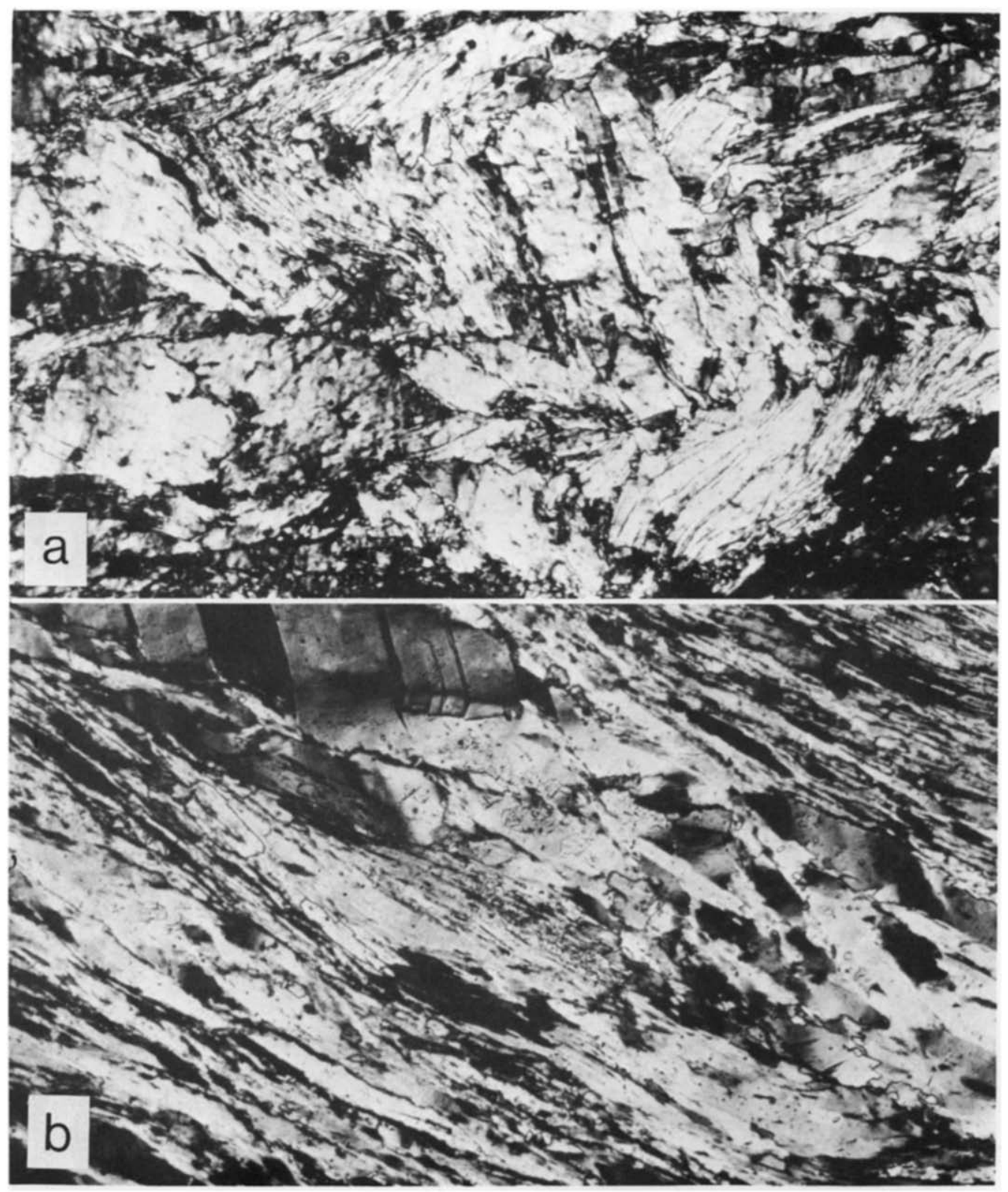

Fig. 2. Details of white mica optical microstructure (a) Microfolded type- $A$ porphyroclast. Note the serration of kink band boundaries and concentration of recrystallization at microfold hinges. (b) Type-A porphyroclast completely recrystallized to type- $B$ crystals. The mylonitic foliation runs NW-SE. (a) and (b) were taken from specimen $\mathrm{Pt} 458$. 


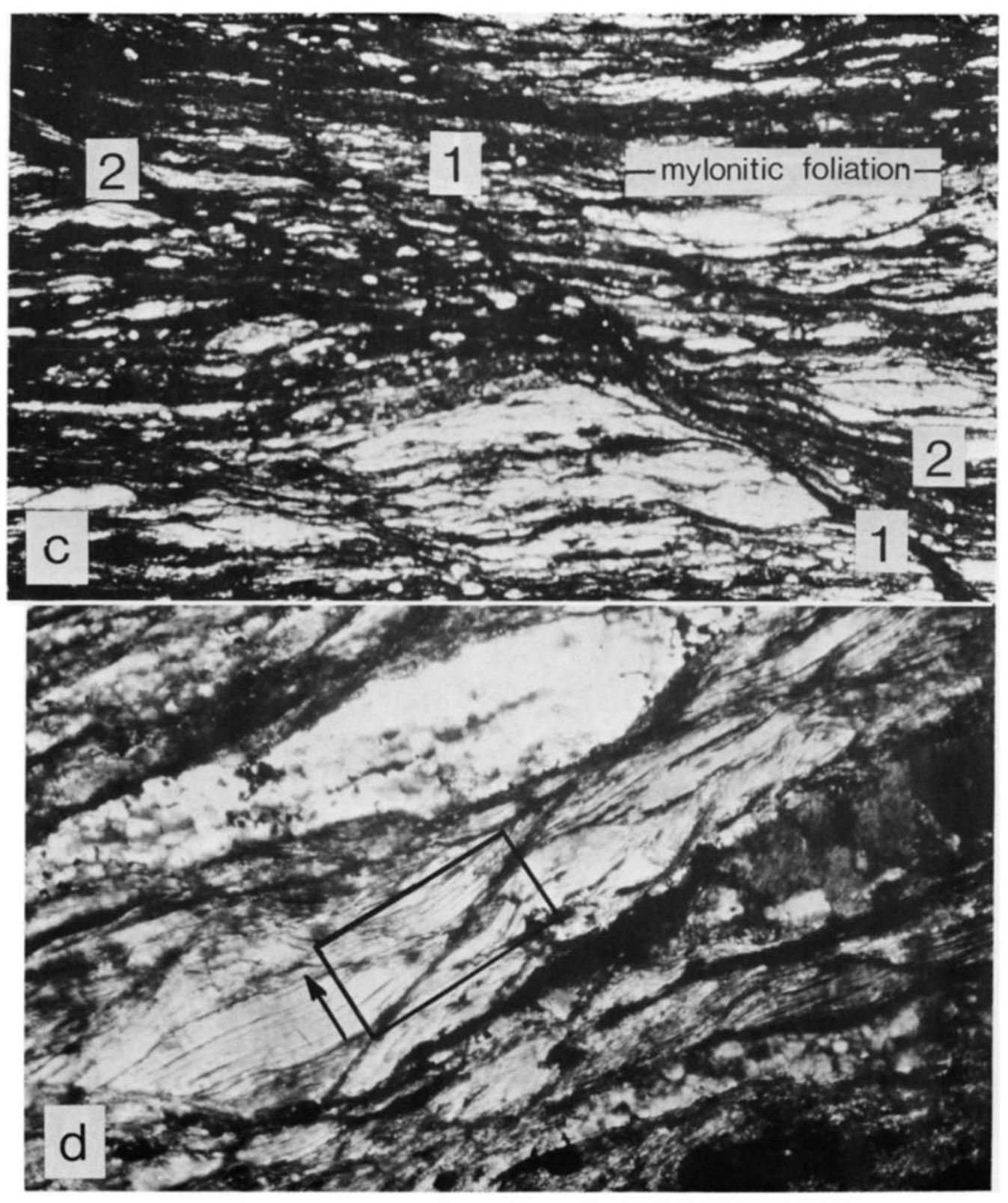




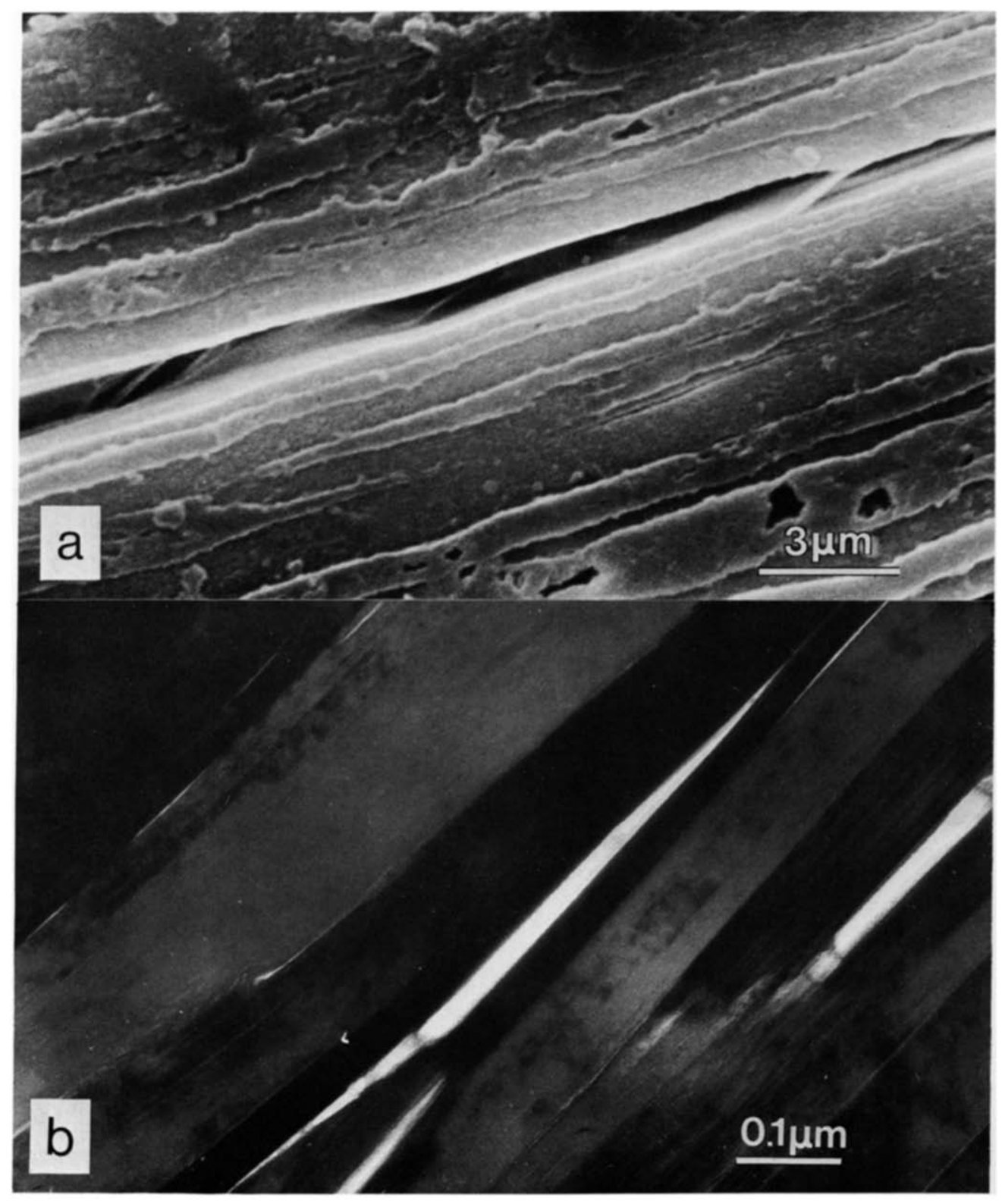




\section{J. H. BEHRMANN}

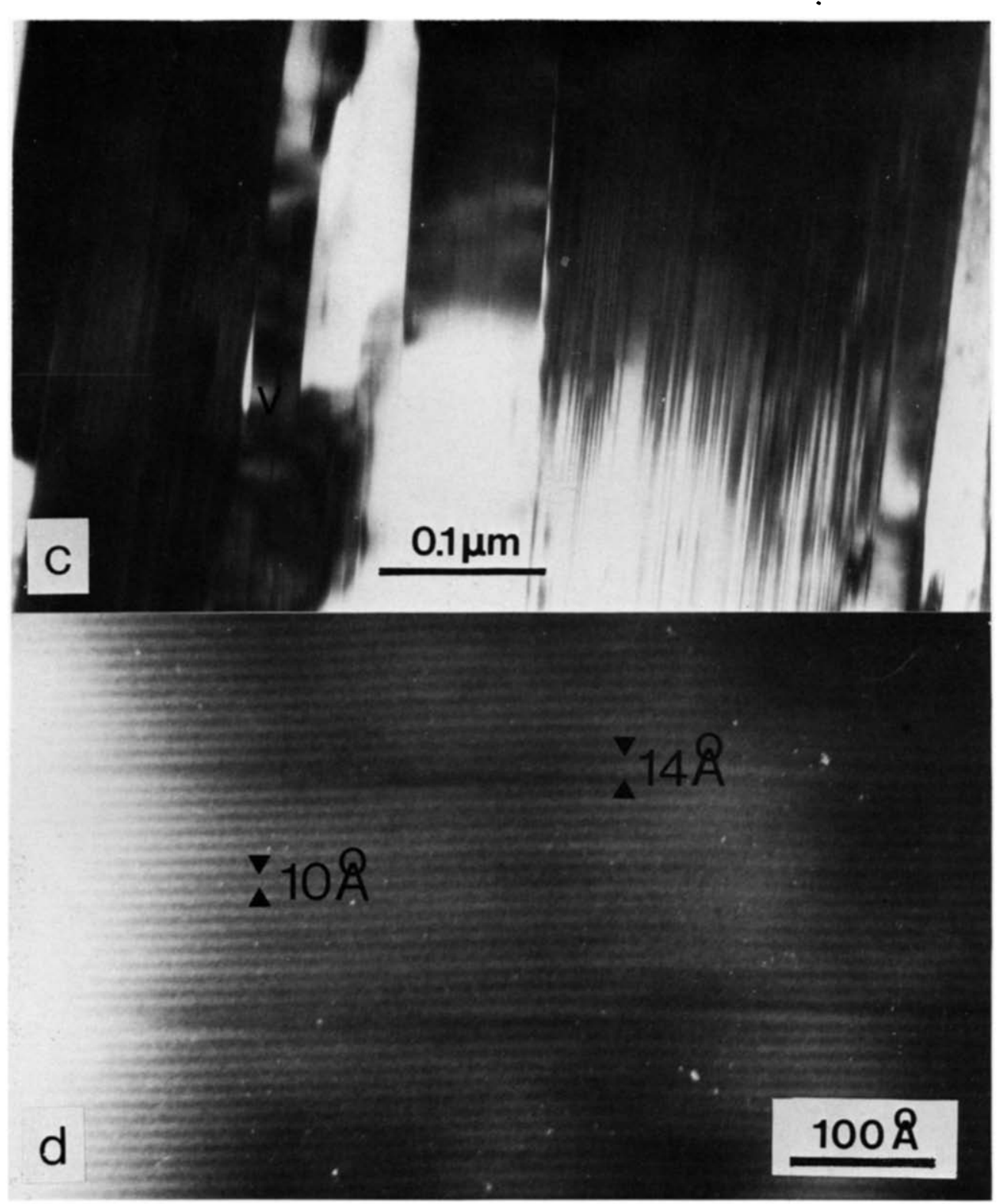

Fig. 3 cont. (c) TEM microstructure of type- $C$ white mica in Pt458. Note that there is no significant bending of (001). An elliptical void decorates a low angle grain boundary (v). (d) Direct lattice image of the $10 \AA$ interplanar spacings of (001) in a type- $C$ crystal. Note the two $14 \AA$ irregularities due to single layer of chlorite. All photographs were taken in bright field. 


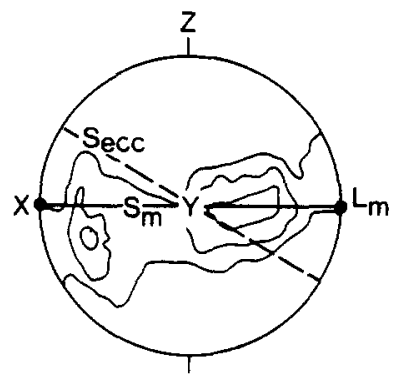

b

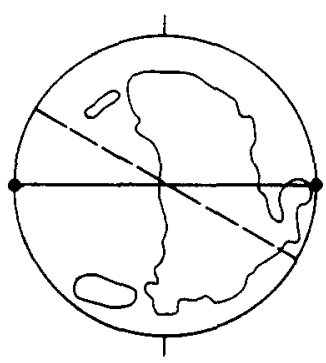

C

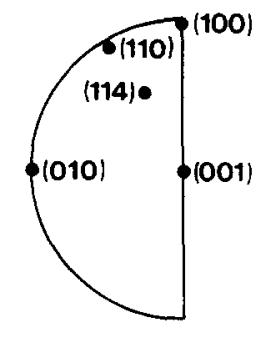

Fig. 4. Crystallographic preferred orientation of white mica in specimen B97. (a) Pole figure of (110). Contours are 1, 2.3x uniform distribution. $S_{m}$ is the mylonitic foliation trace, $L_{m}$ is the stretching lineation, $S_{\text {ecc }}$ is the trace of the extensional crenulation cleavage. $X, Y, Z$, are the inferred positions of the long, intermediate, and short axes of the finite strain ellipsoid. (b) Pole figure of (114). Sign convention is as in (a), contour is $1 \times$ uniform distribution. (c) Pole figure of some diffracting planes of muscovite. All pole figures are equal area, lower hemisphere projections.

reflections have been measured in specimen $B 97$. This is a very fine grained ultramylonite with a compositional banding (mylonitic foliation) on a millimetre scale. The sample has an estimated composition of $70 \%$ white mica, $20 \%$ very fine grained $(<10 \mu \mathrm{m})$ quartz and $10 \%$ coarse oligoclase porphyroclasts. The bulk of the white mica is type- $C$, with remnant domains of coarser, colourless type- $B$ crystals. A single set of extensional crenulation cleavages $(e c c)$ cuts the mylonitic foliation $\left(S_{m}\right)$ at a $30-40^{\circ}$ angle, causing asymmetric warping of the micaceous layers (Fig. 2c). The compositional banding is the enveloping surface. Deformed quartz layers in the specimen have a pronounced stretching lineation $\left(L_{m}\right)$.

The (110) pole figure has a moderate preferred orientation along a great circle inclined at $15^{\circ}$ to the foliation. Two discrete maxima lie on this girdle at $90^{\circ}$ to each other, and at angles with the extension direction of 60 and $30^{\circ}$ (Fig. 4a). The obliquity of the (110) girdle with respect to the mesoscopic foliation is caused by the antithetic rotation of the mica between the extensional crenulation cleavage domains (Platt \& Vissers 1980). The absence of a second (110) girdle parallel to the ecc trace, as one would expect to occur, is a volumetric effect: the total proportion of material in the ecc domains is very small. The (114) pole figure has a weaker expression with a kidney shaped outline on a great circle at a high angle to the foliation trace. Two smaller maxima are situated next to the ends of the kidney (Fig. 4b).

Both pole figures constrain a pronounced maximum of $(001)$ poles at an angle of about $15^{\circ}$ to the foliation normal, nearly orthogonal to the great circle distribution of the (110) poles. If the axial symmetry of the specimen around the pole to (001) was to be perfect the (114) poles should form a small circle girdle around this point inclined at $15^{\circ}$ to the foliation normal. Considering the crystal symmetry and the bimodal distribution of the (110) poles, a broad double maximum distribution around the maximum elongation direction $\left(L_{m}\right)$ and the intermediate finite strain axis can be predicted for $(100)$ and $(010)$ poles. This defines an approximately orthorhombic textural symmetry, and is consistent with the results obtained by Sander (1930) using optical analysis.
Slip systems reported for white mica are compiled and discussed by Nicolas \& Poirier (1976, p. 195). One way to explain the preferred orientation pattern in B97 is by intracrystalline slip and rotation of $(001)\langle 100\rangle$ and $(001)\langle 1 / 2100+1 / 2110\rangle$. The orthorhombic textural symmetry arises by preferential activation of slip on one of the two directions, depending on the original orientation of the crystal with respect to the principal kinematic axes ( $X, Y, Z$; see Fig. 4a).

\section{MICROCHEMISTRY OF EXTENSIONAL CRENULATION CLEAVAGE}

The large, sheared type- $A$ porphyroclast shown in Fig. 2(d) was analyzed on a grid with $10 \times 10 \mu \mathrm{m}$ spacing for the four major elements of white mica (K, Fe, Al, $\mathrm{Si})$. The results were plotted as elemental maps of weight percentages (Figs. 5a-d). The trace of the extensional crenulation cleavage, running WSW-ENE, is visible in each of the four maps. In the extensional crenulation cleavage silicon decreases by up to $3 \mathrm{wt} \%$, except for the two patches on the lower left quadrant: results here are generally disturbed by low totals due to poor quality of the polished section surface. Totals here run up to about $5 \%$ low. Potassium has a tendency to decrease within the micro-shear zone by $1-2$ wt $\%$. Aluminium diminished by up to half of its original weight fraction. Iron, however, shows variable but large increases from its original average content of $3 \mathrm{wt} \%$. Considering the possibilities of isomorphic substitution in white mica (Warshaw \& Roy 1961), $\mathrm{Al}^{3+}$ can be replaced by $\mathrm{Fe}^{3+}$ on the octahedral cation sites in the crystal lattice. Figure 6 demonstrates that these ions form such a substitution pair. The slope in the correlative weight percentage plot is just slightly less than -2.07 , as it should be for ideal one-to-one substitution. $\mathrm{Mg}$ contents are low, and vary between 0.5 and $1.5 \mathrm{wt} \%$ for parent porphyroclast and shear zone, respectively.

\section{COMPOSITION-VOLUME RELATIONSHIPS}

The average of analyses of the standard nine major elements for type- $A / B$ and type- $C$ white mica in $\mathrm{Pt} 458$ 
a
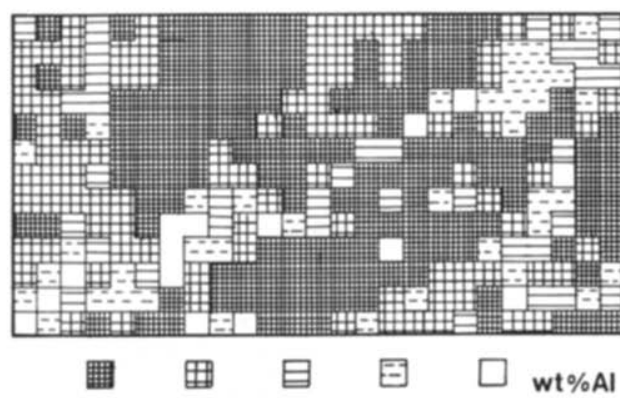

$\geqslant 18.3<18.3<16.0<13.7<10.3$

c

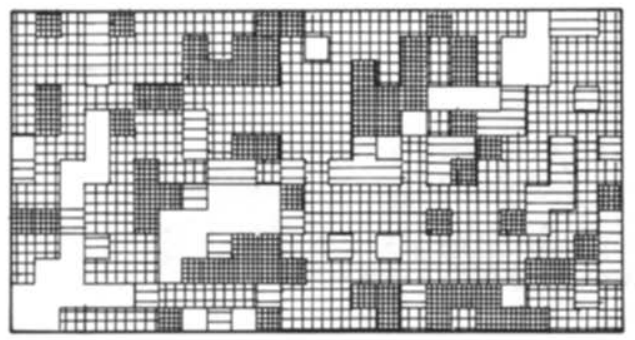

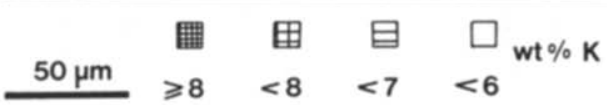

b

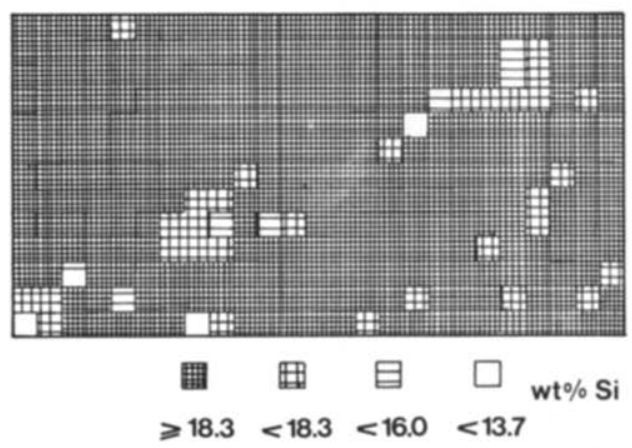

d

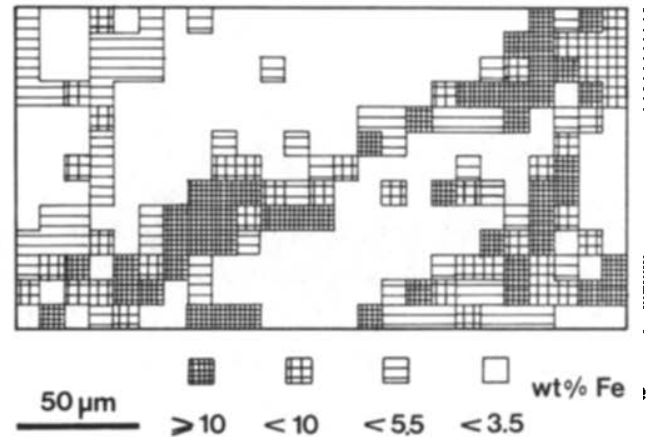

Fig. 5. Elemental maps showing the weight percentage distribution of Al, Si, K and Fe in the framed part of Fig. $2 \mathrm{~d}$.

are listed in Table 1. Type- $C$ analyses were exclusively done at several extensional crenulation cleavage sites in sheared type- $A / B$ porphyroclasts. The approximately constant totals indicate that no significant hydration accompanied the recrystallization from type- $A / B$ to $-C$.

If we now consider the two groups $(A / B$ and $C)$ of analyses as being 'bulk samples', a mass balance calculation can be done for the two phase system on the basis of equation (14) of Gresens (1967):

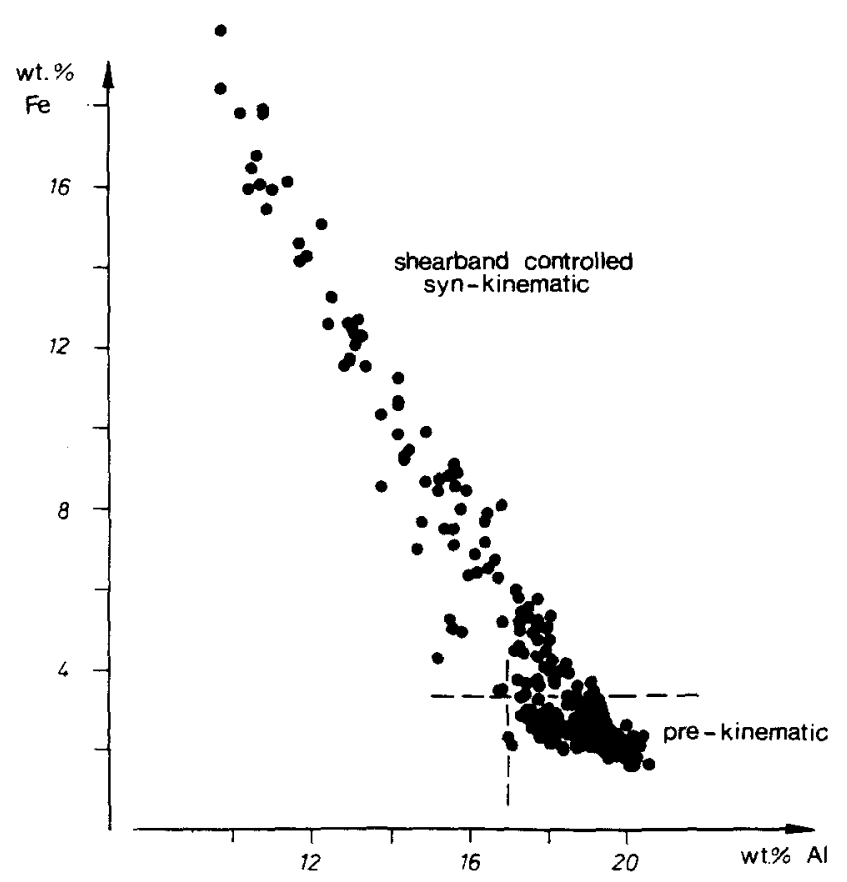

Fig. 6. Correlation of weight percentage content of $\mathrm{Al}$ and $\mathrm{Fe}$ in the analyses of Fig. 5. For discussion see text.

$$
100 f_{v} \frac{g_{B}}{g_{A}} c_{n}{ }^{B}-c_{n}{ }^{A}=x_{n}
$$

Where $f_{v}$ is a volume factor to express gains or losses, $g_{A}$ and $g_{B}$ are the specific gravities of the mineral phases involved (taking data from Tröger, 1971; their ratio in our case is 0.993$), c_{n}{ }^{A}$ and $c_{n}{ }^{B}$ are the weight fractions of the chemical components, and $x_{n}$ is the amount of component $n$ lost or gained. The results are plotted on a diagram correlating volume factors, and gains and losses in $\%$ of the component weight fraction during the recrystallization process (Fig. 7). A value for $f_{v}$ can now be chosen at a point where the graphs of several components simultaneously cross the zero gain-loss line (Gresens 1967). In Fig. 7, Fe and Al should be excluded, as they are demonstrably involved in an isovolumetric exchange reaction. The minor components $(\mathrm{Na}, \mathrm{Ca}$, $\mathrm{Mg}, \mathrm{Ti}, \mathrm{Mn}$ ) show large changes, but tend to compensate each other. Si and K, both major components, have a

Table 1. Microchemical analysis of white mica (Pt458)

\begin{tabular}{|c|c|c|c|}
\hline & \multirow{2}{*}{$\begin{array}{c}\text { Type- } A / B \\
\text { (18 porphyroclasts) } \\
\text { wt. } \%\end{array}$} & & \multirow{2}{*}{$\begin{array}{c}\text { Type- } C \\
\text { (14 ecc sites) } \\
\text { wt. } \%\end{array}$} \\
\hline & & $c_{n}{ }^{4} c_{n}{ }^{B}$ & \\
\hline $\mathrm{Na}_{2} \mathrm{O}$ & $1.43 \pm 0.37$ & & $0.69 \pm 0.41$ \\
\hline $\mathrm{MgO}$ & $0.69 \pm 0.21$ & & $1.42 \pm 0.75$ \\
\hline $\mathrm{Al}_{2} \mathrm{O}_{3}$ & $34.35 \pm 0.73$ & & $30.27 \pm 3.60$ \\
\hline $\mathrm{SiO}_{2}$ & $46.59 \pm 1.04$ & & $+3.82 \pm 3.07$ \\
\hline $\mathrm{K}_{2} \mathrm{O}^{\circ}$ & $8.59 \pm 0.70$ & & $8.00 \pm 1.08$ \\
\hline $\mathrm{CaO}$ & $0.11 \pm 0.12$ & & $0.33 \pm 0.23$ \\
\hline $\mathrm{TiO}_{2}$ & $0.31 \pm 0.11$ & & $0.96 \pm 1.62$ \\
\hline $\mathrm{MnO}$ & $0.01 \pm 0.01$ & & $0.02 \pm 0.02$ \\
\hline $\mathrm{Fe}_{2} \mathrm{O}_{3}$ & $3.54 \pm 1.68$ & & $10.37 \pm 5.50$ \\
\hline Total & 95.62 & & 95.88 \\
\hline
\end{tabular}




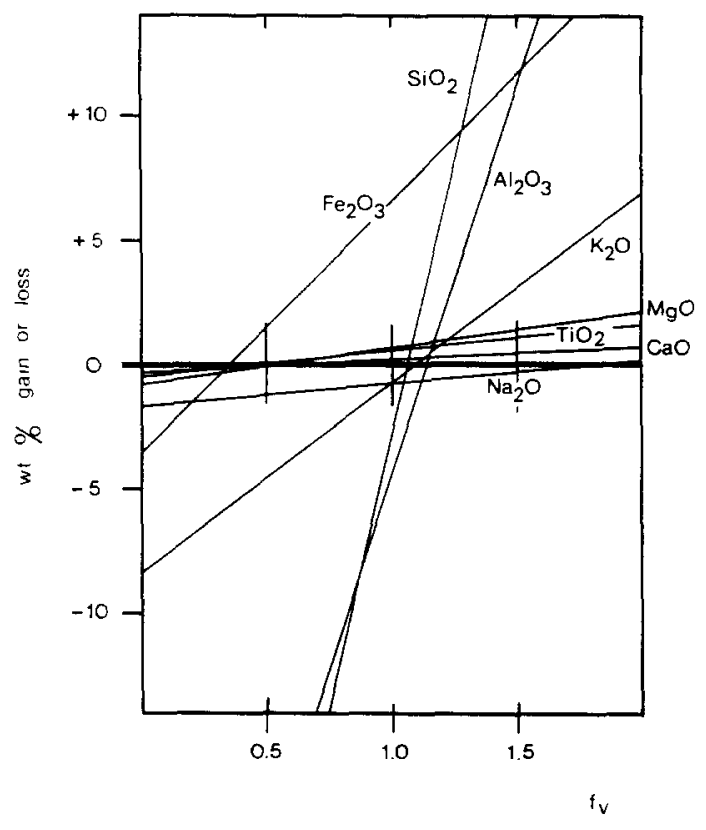

Fig. 7. Composition-volume diagram for solutions of equation (14) of Gresens (1967) using the analytical data listed in Table 1.

nearly common intercept at $f_{v}=1.1$. The conclusion is that $\mathrm{Si}$ and $\mathrm{K}$ were either immobile during recrystallization, or equally mobile. On a normal $P / T$ path in retrograde metamorphism ( $P$ and $T$ decreasing simultaneously), the $\mathrm{Si}^{4+}$ content in phengites should not vary significantly (Velde 1967). This favours the assumption of immobility. Hence, the average volume increase in the selection of micro-shear zones studied in Pt458 would be around $10 \%$. This is outside an additive error defined by the cumulative analytical variability of Si and $\mathrm{K}$ (about 6\%).

\section{DISCUSSION}

The microstructural observations made on polarized light and electron microscope scales are broadly similar to those of other workers (Etheridge \& Hobbs 1974, Bell \& Wilson 1981), except for the widespread occurrence of basal cleavage cracks in type- $A / B$ crystals. This is a common fracture phenomenon in a range of materials with a single cleavage slip plane, such as zinc (Honeycombe 1968), beryllium or cold deformed biotite (Nicolas \& Poirier 1976). If fracture was a continuous process in type- $A / B$ grains, some of the dilation cracks (Fig. 3a) may have been large enough to stabilize isochemical nuclei and promote their growth, if we accept the reasoning of Etheridge \& Hobbs (1974 p. 120). The kinetics of this process may have been largely enhanced by the increase in fluid mobility due to dilation. Direct evidence for the development of bulge nuclei (Bailey \& Hirsch 1962), such as crystallographic continuity of grains with the neighbours of their hosts, or marked dislocation density gradients, is lacking.

Recrystallization from type- $A / B$ to type- $C$ white mica involves a compositional change. This process seems to be confined to extensional crenulation cleavages or micro-boudinage necks, that is, potential concentration

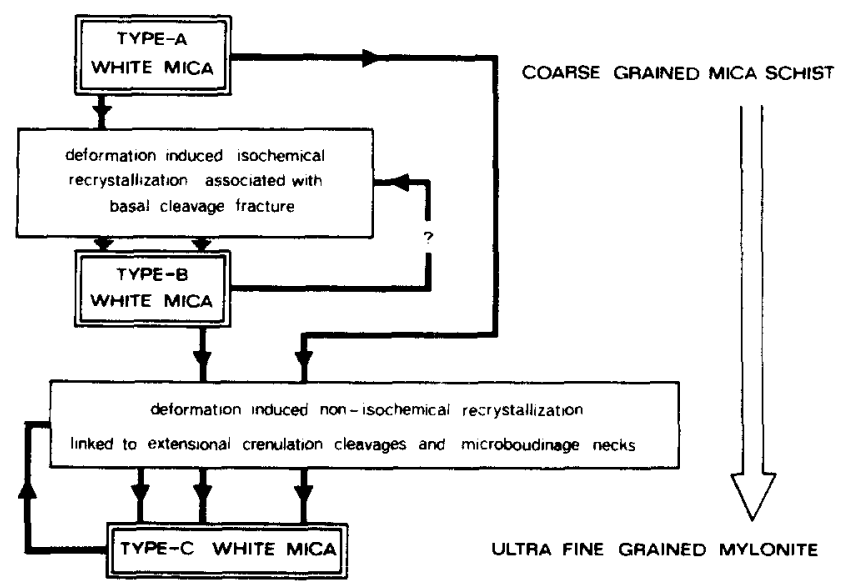

Fig. 8. Summary of the deformation and recrystallization processes involved in the production of an ultra fine grained mylonite from a coarse grained mica schist parent rock in low grade metamorphism

sites of stress and strain energy. A driving force for nucleation may be provided by chemical free energy differences between muscovite and phengite under the prevailing metamorphic conditions (see discussions in Poirier \& Guillopé 1979, Etheridge \& Hobbs 1974). The microstructural control on recrystallization shows that stored strain energy may activate and/or support the process. The change of free energy within the system can be expressed as:

$$
\Delta G_{\text {total }}=\Delta G_{\text {phase change }}+\Delta G_{\text {strain energy }} .
$$

With $\Delta G_{\text {total }}<0$, the process should be thermodynamically feasible. No quantitative treatment is possible, however, because of the lack of suitable experimental data. The opening of the grain scale microchemical system is a prerequisite for the phase change.

The observed microstructures point to a combined brittle and ductile mode of deformation in type- $A / B$ crystals, involving lattice bending, dilation cracking along (001), and eventual recrystallization at these sites, the rate of which is likely to be controlled by solution transfer.

Deformation of the fine grained type- $C$ mica aggregates was probably dominated by brittle fracture, and solution transfer along voids and grain boundaries. The change in chemistry that accompanied recrystallization suggests that the length of the diffusion paths is greater than for a single type- $A / B$ muscovite assemblage, that is, longer than about $1 \mathrm{~mm}$. Evidence for intracrystalline slip is controversial. The orthorhombic fabric symmetry in specimen B97 supports the idea of slip on, and reorientation of, the basal planes. On the other hand the conspicuous absence of a dislocation substructure denies its importance.

A summary of the probable deformation and recrystallization processes involved in white mica mylonite formation is given in Fig. 8. From the microstructural observations it is not possible to say whether isochemical and non-isochemical recrystallization were simultaneous or not. The fact that two fluids of different composition would have had to coexist on a millimetre scale indicates however that the two stages of recrystallization were separated in time. 
The close microstructural control on the formation of fine grained type- $C$ aggregates suggests that the final microstructure of very fine grained mica mylonites can be generated by continuous formation of extensional crenulation cleavages, and their progressive rotation during flow towards geometrical coincidence with the compositional banding. Observational evidence for this is given by Platt \& Vissers (1980, p. 405), and in Fig. 2(c) of this paper. The dilatancy observed in the ecc domains (see previous paragraph) may lead to a reduction in strength (Casey 1980), hence concentrating strain within the extensional crenulation cleavages. Their progressive rotation during flow away from a direction of maximum resolved shear stress, will inactivate them and cause the formation of new sets (Casey 1980, fig. 5).

Formation of extensional crenulation cleavage requires a strong planar mechanical anisotropy oriented at a high angle to the direction of maximum compressive stress (Cobbold et al. 1971, Platt \& Vissers 1980). The fact that nonisochemical recrystallization of low-iron muscovite (type- $A / B$ ) to a high-iron white mica (type$C$ ) is confined to the later part of the deformation history in our specimens, indicates that such an anisotropy did not exist in the coarse grained, presumably statically annealed mica-schists prior to mylonitization, but was created during early isochemical recrystallization. Also, it could be argued that progressive mylonitization was accompanied by a significant variation in metamorphic conditions. The change from isochemical to nonisochemical recrystallization probably reflects a change of fluid composition, which in turn was made possible by massive retrograde breakdown of subsidiary minerals like garnet or staurolite.

\section{CONCLUSIONS}

(1) The process of syntectonic grain size reduction in the mylonite specimens studied shows a two-stage recrystallization of white mica. Stage one possibly works on nucleation of new crystals at dilatancy sites, and their subsequent growth at the expense of their neighbours. Later recrystallization is non-isochemical and may be driven by differences in strain energy and chemical free energy between the two phases.

(2) Deformation of polycrystalline white mica is probably governed by interactive brittle fracture and diffusional mass transfer along grain boundaries, basal cleavage cracks and voids.

(3) The composition-volume data suggest that deformation in the extensional crenulation cleavages is accompanied by a slight volume increase. The phase change from muscovite to a high-iron white mica in these sites is characterized by a one-to-one substitution of $\mathrm{Fe}^{3+}$ for $\mathrm{Al}^{3+}$.

(4) Progressive deformation led to the formation of a strong mechanical anisotropy (mylonitic foliation) during early isochemical recrystallization. Later deforma- tion was accomplished by shearing along continuously forming sets of extensional crenulation cleavages.

Acknowledgements-I wish to thank R. J. Knipe, J. P. Platt and P Verhoef for stimulating discussion and critical comments on an earlier draft of this paper. Two anonymous referees gave positive and careful criticism. S. M. Schmid and M. Casey made X-ray texture goniometer facilities available at ETH, Zürich. J. P. Platt provided some of the specimens. This work was carried out during the tenure of a Florey European Studentship at The Queen's College, Oxford.

\section{REFERENCES}

Bailey, J. E. \& Hirsch, P. B. 1962. The recrystallization process in some polycrystalline metals. Proc. $R$. Soc. A267, 11-30.

Barber, D. J. 1970. Thin foils of non-metals made for electron microscopy by sputter-etching. J. Mater. Sci. 5, 1-8.

Behrmann, J. H. \& Platt, J. P. 1982. Sense of nappe emplacement from quartz $c$-axis fabrics; an example from the Betic Cordilleras (Spain). Earth Planet. Sci. Lett. 59, 208-215.

Bell, I. A. \& Wilson, C. J. L. 1981. Deformation of biotite and muscovite: TEM microstructure and deformation model. In: The Effect of Deformation on Rocks (edited by Lister, G. S., Behr, H. J.. Weber, K. \& Zwart, H. J.), Tectonophysics 78, 201-228.

Bell, T. H. \& Etheridge, M. A. 1973. Microstructure of mylonites and their descriptive terminology. Lithos 6, 337-348.

Casey, M. 1980 . Mechanics of shear zones in isotropic, dilatant materials. J. Struct. Geol. 2, 143-147.

Cobbold, P. R., Cosgrove, J. W. \& Summers, J. M. 1971. The development of internal structures in deformed anisotropic rocks. Tectonophysics 12, 23-53.

Egeler, C. G. \& Simon, O. J. 1969. Sur la tectonique de la zone Betique (Cordilleres Betiques, Espagne). Koninkl. Ned. Akad. Wetensch. Verh. 25, 1-90.

Etheridge, M. A. \& Hobbs, B. E. 1974. Chemical and deformational controls on recrystallization of mica. Contr. Miner. Petrol. 43, 111-124.

Gresens, R. L. 1967. Composition-volume relationships in metasomatism. Chem. Geol. 2, 47-65.

Honeycombe, R. W. K. 1968. The Plastic Deformation of Metals. Arnold, London.

Knipe, R. J. 1981. The interaction of deformation and metamorphism in slates. In: The Effect of Deformation on Rocks (edited by Lister, G. S., Behr, H. J., Weber, K. \& Zwart, H. J.), Tectonophysics 78, 249-272.

Li, J. G. M. 1962. Possibility of subgrain rotation during recrystallization. J. appl. Phys. 33, 2958-2965.

Nicholas, A. \& Poirier, J. P. 1976. Crystalline Plasticity and Solid State Flow in Metamorphic Rocks. Wiley, New York.

Platt, J. P. 1982. Emplacement of a fold-nappe, Betic orogen, southern Spain. Geology 10, 97-102.

Platt, J. P. \& Vissers, R. L. M. 1980. Extensional structures in anisotropic rocks. J. Struct. Geol. 2, 397-410.

Plessman, W. 1964. Gesteinslösung, ein Hauptfaktor beim Schieferungsprozess. Geol. Mitt. 4, 69-82.

Poirier, J. P. \& Guillope, M. 1979. Deformation induced recrystallization of minerals. Bull. Mineral. 102, 67-74.

Sander, B. 1930. Gefügekunde der Gesteine, Springer, Wien.

Siddans, A. W. B. 1976. Deformed rocks and their textures. Phil. Trans. $R$. Soc. A283, 43-54.

Torres-Roldán, R. L. 1979. The tectonic subdivision of the Betic Zone (Betic Cordilleras, southern Spain): its significance and one possible geotectonic scenario for the westernmost alpine belt. Am. J. Sci. $279,19-52$.

Tröger, W. E. 1971. Optische Bestimmung der gesteinsbildenden Minerale (1), Schweizerbart, Stuttgart

Velde, B. $1967 . \mathrm{Si}^{4+}$ control of natural phengites. Contr. Miner. Petrol. 14, 250-258.

Warshaw. C. M. \& Roy, R. 1961. Classification and a scheme for the identification of layer silicates. Bull. geol. Soc. Am. 72, 1455-1492.

Weber, K. 1981. Kinematic and metamorphic aspects of cleavage formation in very low grade metamorphic slates. In: The Effect of Deformation on Rocks (edited by Lister, G. S. . Behr. H. J., Weber, K. \& Zwart, H. J.), Tectonophysics 78, 291-306.

Wilson, C. J. L. 1980. Shear zones in a pegmatite. A study of albite-mica-quartz deformation. J. Struct. Geol. 2, 203-209. 